DOI: $10.20535 / \mathrm{kpisn} .2020 .4 .226984$

UDC $531.384+534.1+539.3$

\author{
V.P. Legeza* \\ Igor Sikorsky Kyiv Polytechnic Institute, Kyiv, Ukraine \\ *corresponding author: viktor.legeza@gmail.com
}

\title{
MATHEMATICAL PENDULUM MODEL WITH MOBILE SUSPENSION POINT
}

Background. The new dynamic problem, which is posed and solved in this article, is a theoretical generalization of the well-known classical problem of free oscillations of a mathematical pendulum. In the proposed setting, it is new and relevant, and can be successfully used in such fields of technology as vibration protection, vibration isolation and seismic protection of high-rise flexible structures, long power lines, long-span bridges and other large-sized supporting objects. Objective. The aim of the work is to derive the equations of own oscillations of a new mathematical pendulum-absorber, to find a formula for determining the frequency of its small own oscillations and to establish those control parameters that allow you to tune the single-mass pendulum absorber to the frequency of the fundamental tone of the carrier object.

Methods. To achieve this goal, we used the methods of analytical mechanics, namely, the Appel's formalism, as well as the linearization of the obtained differential equations.

Results. A mathematical model is constructed in the work that describes the own oscillations of a new-design mathematical pendulum with a movable (spring-loaded) suspension point with length $L$. The model is a system of differential equations obtained using the Appel's formalism. Based on them, after linearization of nonlinear equations, a formula is established for the frequency of small own oscillations of a pendulum with a mobile suspension point.

Conclusions. It is shown that the frequency of own oscillations of the new mathematical pendulum coincides with the frequency of own oscillations of the classical mathematical pendulum with an equivalent suspension length, which is equal to $L_{\mathrm{eq}}=L+\frac{m g}{k}$. In the case where the suspension point is fixed $(k \rightarrow \infty)$, the frequency formula turns into a well-known formula for the frequency of small own oscillations of a classical mathematical pendulum $\omega=\sqrt{\frac{g}{L}}$. If the stiffness coefficient of elastic elements tends to zero $(k \rightarrow 0)$, then the frequency $\omega$ of the damper also tends to zero. An important structural feature of the proposed pendulum is noted, consisting in the fact that due to the appropriate choice of the three control parameters of the pendulum $(k, L, m)$, its frequency in magnitude can be made any in the range from zero to $\sqrt{\frac{g}{L}}$.

Keywords: mathematical pendulum; moving suspension point; small own oscillations; frequency; Appel's formalism; linearization.

\section{Introduction}

This work is a continuation of the previous theoretical and experimental studies of the author in the field of vibration protection of large-sized bearing objects [1-5]. Such objects include flexible long structures, such as TV towers, radio masts, metal exhaust pipes, long-span bridge crossings and high voltage power lines. The most dangerous for such bearing objects are forced oscillations of various nature, especially in the range of the main frequencies of their own oscillations. To solve this problem, special devices called vibration dampers are used, which are installed on the supporting object and are tuned to the frequency of its main oscillation tone [6-13].

Modern scientific research in the field of developing new methods of vibration protection of bearing objects using vibration dampers is aimed at simplifying their designs, at increasing their reliability, efficiency and durability, reducing size and weight.

There are various types of vibration dampers; they are specially designed for a specific supporting object to combat specific dynamic effects $[1,2$, 8-13]. After installation on a supporting object, these devices become its integral structural elements with all the ensuing requirements for their reliability, durability, corrosion resistance, and ease of tuning, work efficiency.

The theory of vibration protection of loadbearing objects using dampers as additional attached masses is based on Den-Hartog's fundamental research $[6,7]$. 
Recently, considerable attention has been paid to theoretical and experimental questions of vibration suppression of forced oscillations of high-rise buildings [8-13]. This is due to the massive reconstruction of high-rise flexible structures (especially TV towers, radio-musts, metal exhaust pipes, steel chimneys, bridge spans), which have served for more than 30-40 years and require either reinforcement of dangerous sections or other design solutions in connection with the modernization and installation of new equipment on them. In the latter case, new (additional) loads arise that are not provided for by the initial design. Under these conditions, one of the cheapest and structurally simplest solutions is also the development and application of various types of absorbers: pendulum, roller, shock [1, 2, 14-20].

Today, there are a number of vibration dampers that are time-tested and to some extent removed the acuteness of the problem of suppressing forced oscillations. For example, the theory of the dynamics of vibration protection systems with the use of pendulum dampers of forced oscillations has been developed quite deeply $[3,4,8,10,13,18,19$, 20-25]. A number of works propose both theoretical and experimental methods for determining the optimal parameters and tuning the pendulum dampers in order to reduce the level of dynamic effects on various load-bearing objects $[1,2,7,8,16,18-24]$.

However, the development of new methods of vibration protection and the search for means of their implementation continue [4, 5, 13-15, 22].

A rather acute problem is the development, construction and implementation of simple and compact dampers with a low frequency of natural oscillations [1-5], which could provide vibration protection for load-bearing objects in the low-frequency range $(0.5-2.0 \mathrm{rad} / \mathrm{s})$. This is due to the fact that at such low frequencies, the carrier bodies can have very large amplitudes of forced oscillations. For example, in some cases, the deviations of the upper points of the TV towers can be up to 1.5-2 meters or more. Therefore, the absorber tuned to the frequency of the fundamental tone of the supporting object will also have the same amplitudes of its working body (or attached mass).

Structurally close to the proposed damper is a pendulum damper with a fixed suspension point, which is recommended for use by regulatory documents of the construction industry $[8,24,25]$. In its physical essence, it is a mathematical pendulum made in the form of a working body, which is fixed at the lower point of the suspension. The suspension itself is usually a flexible cable (bundle of cables) or a hinge rod. The opposite end of the suspension is rigidly fixed in the upper part of the high-rise structure (supporting body). In addition, the suspension is connected with a high-rise structure by an elastic element with adjustable stiffness, which limits the amplitudes of oscillations (deviations) of the damper working body from the vertical. The damper's working body itself is a steel, cast-iron or reinforced concrete element, and in some cases a liquid tank. The elastic element is made in the form of a steel spring or a system of springs, in a design close to the design of the vibration isolator. Damping in pendulum dampers is realized due to local bending of the cable at the upper point of its fastening relative to the structure.

A significant drawback of such absorbers is that their natural frequency is determined only by the suspension length $L$ of the working body. This design limitation makes it impossible to use them in the low-frequency range of $0.2-2.0 \mathrm{rad} / \mathrm{s}$. The proposed pendulum dampers with a movable suspension point do not have this design flaw and can be successfully used in the low frequency range. The theoretical rationale for this statement will be presented below. The technical solution of the damper in question is protected by the copyright certificate of Ukraine.

For the correct adjustment of the damper, first of all, it is necessary to know the frequency of natural vibrations, which is in a certain dependence on its design parameters. Since in this work an absorber of a new design is considered, first of all it is necessary to determine its natural frequency.

\section{Problem statement}

The goal is to derive the equations of natural vibrations of a new mathematical pendulum-absorber, find a formula for determining the frequency of its small natural oscillations, and establish those control parameters that allow to tuned the pendulum absorber to the frequency of the fundamental tone of the carrier object.

\section{Geometric relations and the derivation of the equations of natural oscillations of a new math- ematical pendulum-absorber}

Thus, let us consider a new dynamic problem of the natural oscillations of a mathematical pendulum with a suspension length, at which the suspension point is movable in the horizontal direction. 
Moreover, it is associated with the initial (equilibrium) position of the pendulum suspension point by a system of elastic elements with equivalent stiffness. In addition, the damper with a viscous drag coefficient $C$ prevents the deviation of the suspension of such a pendulum from the vertical (Figure). The suspension mass in this study is neglected.

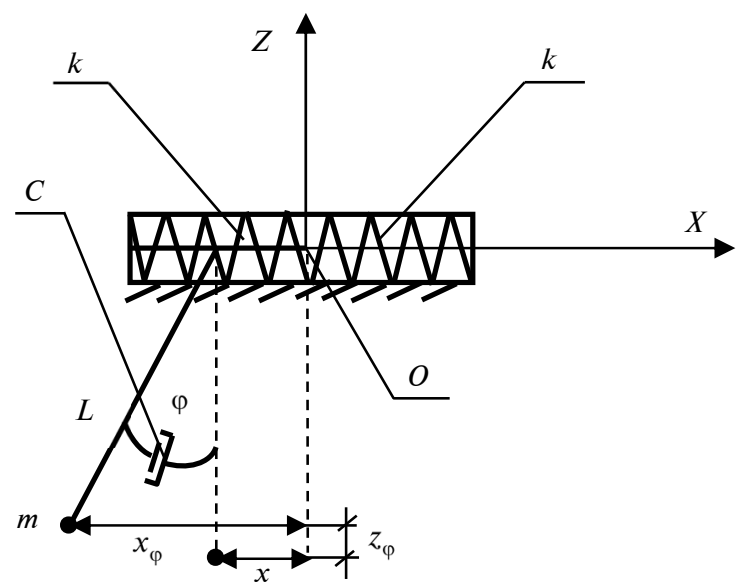

Absorber in the form of a mathematical pendulum with a mobile suspension point

We choose a Cartesian coordinate system $X O Z$ as shown in the Figure. Let us place the origin $O$ at the starting point of the suspension and direct the axis $O X$ horizontally to the right, and the axis $O Z$ vertically up. The mass of the mathematical pendulum (material point) is equal $m$. The suspension mass is neglected. The system of elastic elements that prevent the movement of the pendulum suspension point in the horizontal direction $O X$, has an equivalent stiffness coefficient $k$. We introduce the coordinates $x$ and $\varphi$, where $x$ - the horizontal movement of the pendulum suspension point and $\varphi-$ the deviation angle of the suspension line from the vertical. In addition, we denote by $x_{\varphi}$ moving the mass $m$ along the axis $O X$, and by $z_{\varphi}-$ moving the mass $m$ along the axis $O Z$. Let us write the corresponding geometric relationships that relate the entered parameters and coordinates:

$$
\begin{gathered}
x_{\varphi}=x-L \sin \varphi, \\
z_{\varphi}=L(1-\cos \varphi) .
\end{gathered}
$$

To derive differential equations that describe the natural oscillations of the pendulum, let us use the Appel's formalism, which very quickly and easily leads to the goal [26]. First, let us write the function
$S$ - of acceleration energy (or the Appel's function) in general form:

$$
S=\frac{m\left(\ddot{x}_{\varphi}^{2}+\ddot{z}_{\varphi}^{2}\right)}{2} .
$$

Using relations (1) and (2) let us find expressions for projections of accelerations $\ddot{x}_{\varphi}$ and $\ddot{z}_{\varphi}$ on coordinate axes:

$$
\begin{aligned}
\ddot{x}_{\varphi} & =\ddot{x}+L\left(\dot{\varphi}^{2} \sin \varphi-\ddot{\varphi} \cos \varphi\right), \\
\ddot{z}_{\varphi} & =L\left(\dot{\varphi}^{2} \cdot \cos \varphi+\ddot{\varphi} \cdot \sin \varphi\right) .
\end{aligned}
$$

Let us substitute expressions (4) and (5) into formula (3) and write only those terms of the acceleration function $S$ that contain the second derivatives of the corresponding coordinates. Denote this new function as $S^{*}$ :

$$
S^{*}=\frac{m}{2}\left(\ddot{x}^{2}+L^{2} \ddot{\varphi}^{2}\right)-m L \ddot{x} \ddot{\varphi} \cos \varphi .
$$

Now let us find the expression for the sum of the elementary work $\delta A$ of the elements of the mechanical system at all virtual movements:

$$
\delta A=-k x \cdot \delta x-(m g L \sin \varphi+C \dot{\varphi}) \cdot \delta \varphi,
$$

where $g-$ the acceleration of gravity, $\delta x-$ elementary (virtual) movement of the pendulum suspension point along the $O X$ axis; $\delta \varphi$ - elementary angle of deviation of the suspension line from the vertical $O Z$.

Let us write the Appel's equations in general form:

$$
\frac{\partial S^{*}}{\partial \ddot{x}}=Q_{x}, \frac{\partial S^{*}}{\partial \ddot{\varphi}}=Q_{\varphi},
$$

where $Q_{x}$ and $Q_{\varphi}-$ generalized forces related to the entered coordinates $x$ and $\varphi$ respectively.

Using the introduced generalized forces, we write the expression for virtual work:

$$
\delta A=Q_{x} \cdot \delta x+Q_{\varphi} \cdot \delta \varphi .
$$

Having determined the generalized forces $Q_{x}$ and $Q_{\varphi}$ from expressions (7) and (9), we substitute them into the system of equations (8) taking into account the expression (6):

$$
m \ddot{x}-m L \ddot{\varphi} \cos \varphi=-k x,
$$




$$
m L^{2} \ddot{\varphi}-m L \ddot{x} \cos \varphi=-m g L \sin \varphi-C \dot{\varphi} .
$$

After some transformations, system (10), (11) will take the following form:

$$
\begin{gathered}
\ddot{x}-L \ddot{\varphi} \cos \varphi=-\frac{k}{m} x, \\
L \ddot{\varphi}-\ddot{x} \cos \varphi=-g \sin \varphi-\frac{C}{m L} \dot{\varphi} .
\end{gathered}
$$

The system of nonlinear differential equations (12), (13) is a mathematical model that describes the dynamic behavior of a new mathematical pendulum-absorber.

Definition and analysis of the formula for the frequency of small natural oscillations of a new pendulum-absorber

Consider the oscillatory process of a pendulum at small angles $\varphi$. Thus, assuming that the angles $\varphi$ are small and there is no damping (provided $C=0$ ), we linearize the system of equations (12), (13). As a result, we obtain a new system of linear differential equations that describes the small own oscillations of a new pendulum:

$$
\begin{aligned}
\ddot{x}-L \ddot{\varphi} & =-\frac{k}{m} x, \\
L \ddot{\varphi}-\ddot{x} & =-g \varphi .
\end{aligned}
$$

Comparing equations (14) and (15), we immediately obtain the relationship between the coordinates $x$ and $\varphi$ :

$$
-\frac{k}{m} x=g \varphi, \text { or } x=-\frac{m g \varphi}{k} .
$$

Substituting relation (16) into equation (15), we obtain a differential equation with respect to the angle $\varphi$ :

$$
\left(L+\frac{m g}{k}\right) \ddot{\varphi}+g \varphi=0 .
$$

From equation (17) it is already easy to obtain the formula for the desired frequency:

$$
\omega=\sqrt{\frac{g}{L+\frac{m g}{k}}} .
$$

Let us analyze formula (18).
Firstly, the frequency of a new pendulum with a moving suspension point coincides with the frequency of the equivalent classical mathematical pendulum with a suspension length that is equal to $L_{\text {eq }}=L+\frac{m g}{k}$.

Secondly, it is obvious that the frequency of such a pendulum non-linearly depends not only on the length $L$ of its suspension, but also on two new parameters: the mass $m$ of the body on the suspension and the stiffness coefficient $k$ of the system of elastic elements installed at the suspension point.

This makes it possible to simply change the frequency of the natural oscillations of the pendulum in a wide range, namely from the magnitude $\sqrt{\frac{g}{L}}$ (frequency of the classical mathematical pendulum), when $k \rightarrow \infty$, and to zero, when $m \rightarrow \infty$ or $k \rightarrow 0$.

In the case when $k \rightarrow \infty$, the pendulum suspension point is fixed (it is rigidly fixed), and the formula for the frequency $\omega=\sqrt{\frac{g}{L}}$ of natural oscillations coincides with the well-known formula for the frequency of small oscillations of a classical mathematical pendulum with a suspension length $L$.

If the stiffness coefficient $k$ is small (that is $k \rightarrow 0$ ), then the length of the equivalent suspension of the pendulum tends to infinity: $L_{\mathrm{eq}} \rightarrow \infty$.

Thus, if the damper parameter $k \rightarrow 0$, then the frequency $\omega$ of the natural oscillations of the pendulum tends to zero. That is why the damper parameter $k$ is one of the powerful regulators of the damper's natural frequency, which has a low natural vibration frequency and can be used to dampen forced oscillations of load-bearing objects in the low frequency range.

Another interesting case of degeneration of the pendulum damper arises when the suspension length of the pendulum is zero $(L=0)$. In this case, the formula for the natural frequency of the pendulum is simplified and takes the following form:

$$
\omega=\sqrt{\frac{k}{m}} .
$$

In this case, the pendulum turns into a harmonic oscillator with a point mass $m$, which performs horizontal oscillations near the equilibrium point $O$ due to compression-tension of a system of elastic elements with a stiffness coefficient $k$.

Thirdly, the denominator of the radical expression is always larger than the value $L$, that is 
$L+\frac{m g}{k}>L$, since all parameters on the left in the inequality are positive. This fact is new and important in the design of effective dampers of forced vibrations in the low frequency range. This explains the phenomenon that was noted above.

While the frequency in classical pendulum dampers is determined by the choice of only one parameter $L$, in the new technical solution it can be adjusted by changing three parameters $m, k, L$. Moreover (which is very important), it can be made close to zero, while this cannot be done using classical pendulums, the frequency of which is limited from below by a value $\sqrt{\frac{g}{L}}$. For example, in order to realize a low oscillation frequency equal to $1 \mathrm{rad} / \mathrm{s}$, it is necessary to select a pendulum suspension length of approximately ten meters. Obviously, such a damper is simply physically impossible to place on a carrier body.

Thus, the design of the new pendulum allows us to offer such a damper in which it is possible to realize frequencies from the lowest range due to the appropriate choice of its three parameters $m, k, L$.

\section{Conclusions}

In this paper, a new mathematical model is proposed that describes the natural oscillations of a mathematical pendulum with a moving suspension point with length $L$. Structurally, the mobility of the pendulum suspension point in the horizontal direction is realized due to compression - stretching of elastic elements with an equivalent stiffness coefficient $k$.

Based on the Appel's formalism, differential equations are described that describe the natural oscillations of the pendulum, and a formula is established for the frequency of its small oscillations.

It is shown that this frequency coincides with the frequency of the equivalent classical mathematical pendulum with a suspension length that is equal to $L_{\mathrm{eq}}=L+\frac{m g}{k}$. In the case where the suspension point is fixed (if $k \rightarrow \infty$ ), the resulting formula coincides with the well-known formula for the frequency of small natural oscillations of a classical mathematical pendulum.

It is also shown that due to the appropriate choice of the three control parameters of the pendulum, its frequency in magnitude can be made any in the range from zero to $\sqrt{\frac{g}{L}}$.

Further scientific research will be aimed at constructing a dynamic model of the joint movement of the new vibration-protective system "bearing object - pendulum damper with a moving suspension point", which is under the influence of harmonic excitation with a constant frequency.

This study will be useful for scientific experts in the field of theoretical mechanics, dynamics of machines and supporting long-term construction objects, and will also be of interest to developers of special vibration-protective devices used to suppress forced oscillations of large-sized flexible objects).

\section{References}

[1] V.P. Legeza, Vibration Protection of Dynamic Systems with Roller Dampers. Kyiv, Ukraine: Chetverta Khvylya, 2010,280 p.

[2] V.P. Legeza, Theory of Vibration Protection of Systems Using Isochronous Roller Dampers: Models, Methods, Dynamic Analysis, Technical Solutions. Saarbrucken, Germany: Lambert Academic Publishing, 2013, 108 p.

[3] Z. Hu et al., "Non-linear model of the damping process in a system with a two-mass pendulum absorber", Intellig. Syst. Applicat., Systems and Applications, vol. 11, no. 1, pp. 67-72, 2019. doi: 10.5815/ijisa.2019.01.07

[4] V.P. Legeza et al., "Suppression of vibrations of wires and cables using a two-mass pendulum damper", Elect. Syst. Netw., no. 2, pp. 7-13, 2016.

[5] Zhengbing $\mathrm{Hu}$ et al., "Mathematical model of the damping process in a one system with a ball vibration absorber", Int. J. Intellig. Syst. Applicat., vol. 10, no. 1, pp. 24-33, 2018. doi: 10.5815/ijisa.2018.01.04

[6] J.P. Den Hartog, Mechanics. Mineola: Dover Publications, 464 p.

[7] J.P. Den Hartog, Mechanical Vibrations. Crastre Press, 2008, 496 p.

[8] B.G. Korenev and L.M. Reznikov, Dynamic Vibration Absorbers: Theory and Technical Applications. Chichester, UK: John Wiley and Sons Ltd., 1993, 368 p.

[9] Dynamic Response of Lattice Towers and Guyed Masts. M.K.S. Madugula, Ed. Reston: SEI\&ASCE, 2002, 264 p.

[10] S.G. Kelly, Mechanical Vibrations: Theory and Applications. Cengage Learning, 2012, 672 p.

[11] "Dynamics of Coupled Structures", in Proc. the 33rd IMAC, A Conference and Exposition on Structural Dynamics, vol. 4, M. Allen et al., Eds. Springer International Publishing, 2015, 173 p. doi: 10.1007/978-3-319-15209-7 
[12] M. Geradin and D.J. Rixen, Mechanical Vibration: Theory and Applications to Structural Dynamic, 3rd ed. Chichester, UK: John Wiley and Sons Ltd., The Atrium, 2015, 616 p.

[13] J.A. Karnovsky and E. Lebed, Theory of Vibration Protection. Switzerland: Springer International Publishing, 2016,673 p.

[14] J. Naprstek and C. Fischer, "Non-holonomic planar and spatial model of a ball-type tuned mass damping device", in Proc. Engineering Mechanics-2017, Svratka, Czech Republic, May 15-18, 2017, pp. 698-701.

[15] J. Naprstek and C. Fischer, "Forced movement of a ball in spherical cavity under kinematic excitation", in Proc. Engineering Mechanics-2018, Svratka, Czech Republic, May 14-17, 2018, pp. 573-576. doi: 10.21495/91-8-573

[16] H.W. Klein and W. Kaldenbach, "A new vibration damping facility for steel chimneys", in Proc. Conf. Mechanics in Design, Trent University of Nottingham, UK, 1998, pp. 265-273.

[17] T. Dahlberg, "On optimal use of the mass of a dynamic vibration absorber", J. Sound and Vibrat., vol. 132, no. 3, pp. 518-522, 1989. doi: $10.1016 / 0022-460 x(89) 90645-7$

[18] B.V. Ostroumov, "Dynamic vibration damper in the form of an inverted pendulum with damping", Bulletin of Higher Educational Institutions. Ser. Building, no. 9, pp. 36-38, 2002.

[19] B.V. Ostroumov, "Calculation of a structure with a dynamic vibration damper", Industrial and Civil Building, no. 5, pp. 18-22, 2003

[20] B. Diveyev, "Different type vibration absorbers design for beam-like structures", in Proc. ICSV19, Vilnius, Lithuania, July 8 12, 2012, pp. 1499-1506.

[21] B. Diveyev et al., "Influence of vibration protection object parameters and dynamic vibration damper on energy efficiency of vibration absorption", Scientific Notes of Lutsk National Technical University, vol. 42, pp. 81-87, 2013.

[22] I.A. Vikovich et al., "Application of different types of pendulum dynamic vibration dampers”, Bulletin of the National Transport University, vol. 29, no. 1, pp. 26-33, 2014.

[23] B. Diveyev et al., "Different type vibration absorbers design for elongated console structures", Scientific Notes of Lutsk National Technical University, vol. 41, pp. 10-16, 2014.

[24] B.G. Korenev, "Dynamic vibration dampers", in Proc. International Symposium Vibration Protection in Construction, Leningrad, SU, 1984, pp. 7-17.

[25] B.G. Korenev and I.M. Rabinovich, Dynamic Calculation of Buildings and Structures: Designer's Handbook. Moscow, SU: Stroyizdat, 1984, $304 \mathrm{p}$.

[26] A.I. Lurie, Analitical Mechanics. Berlin, Heidelberg: Springer, 2002, 864 p.

\section{В.П. Легеза}

\section{МОДЕЛЬ МАТЕМАТИЧНОГО МАЯТНИКА З РУХОМОЮ ТОЧКОЮ ПІДВІСУ}

Проблематика. Нова динамічна задача, яка поставлена та розв'язана в цій статті, $€$ теоретичним узагальненням відомої класичної задачі про вільні коливання математичного маятника. У запропонованій постановці вона є новою, актуальною й успішно може бути використана в таких галузях техніки, як віброзахист і сейсмозахист висотних гнучких споруд, протяжних ліній електропередач, мостів із довгими прогонами та інших великогабаритних несучих об'єктів.

Мета дослідження. Вивести рівняння власних коливань нового математичного маятника-гасника, знайти формулу для визначення частоти його малих власних коливань і встановити ті регулюючі параметри, які дають змогу налаштовувати одномасовий маятниковий гасник на частоту основного тону несучого об'єкта.

Методика реалізації. Для досягнення поставленої мети в роботі використовувалися методи аналітичної механіки, а саме рівняння Апеля, а також лінеаризація отриманих диференціальних рівнянь.

Результати дослідження. Побудовано математичну модель, яка описує власні коливання математичного маятника нової конструкції з рухомою (підпружиненою) точкою підвісу довжини $L$. Модель являє собою систему диференціальних рівнянь, отриманих із залученням формалізму Аппеля. На їх основі після лінеаризації нелінійних рівнянь встановлено формулу для частоти малих власних коливань маятника з рухомою точкою підвісу.

Висновки. Показано, що частота власних коливань нового математичного маятника збігається з частотою власних коливань класичного математичного маятника з еквівалентною довжиною підвісу, яка дорівнює $L_{\mathrm{eq}}=L+\frac{m g}{k}$. У випадку, коли точка підвісу $€$ нерухомою $(k \rightarrow \infty)$, частотна формула перетворюється на відому формулу для частоти малих власних коливань класичного математичного маятника $\omega=\sqrt{\frac{g}{L}}$. Якщо ж величина коефріцієнта жорсткості пружних елементів прямує до нуля $(k \rightarrow 0)$, то частота $\omega$ гасителя також прямує до нуля. Відзначено важливу конструктивну особливість запропонованого маятника, яка полягає в тому, що за завдяки відповідному вибору трьох регулюючих параметрів маятника $(k, L, m)$ його частоту за величиною за потреби можна зробити довільною в діапазоні від нуля до $\sqrt{\frac{g}{L}}$ ).

Ключові слова: математичний маятник; рухома точка підвісу; малі власні коливання; частота; формалізм Аппеля; лінеаризація. 


\section{В.П. Легеза}

\section{МОДЕЛЬ МАТЕМАТИЧЕСКОГО МАЯТНИКА С ПОДВИЖНОЙ ТОЧКОЙ ПОДВЕСА}

Проблематика. Новая динамическая задача, которая поставлена и решена в данной статье, является теоретическим обобщением известной классической задачи о свободных колебаниях математического маятника. В предложенной постановке она является новой, актуальной, и с успехом может быть использована в таких областях техники, как виброзащита, виброизоляция и сейсмозащита высотных гибких сооружений, протяженных линий электропередач, мостов с длинными пролетами и других крупногабаритных несущих объектов.

Цель исследования. Вывести уравнения собственных колебаний нового математического маятника-гасителя, найти формулу для определения частоты его малых собственных колебаний и установить те регулирующие параметры, которые позволяют настраивать одномассовый маятниковый гаситель на частоту основного тона несущего объекта.

Методика реализации. Для достижения поставленной цели в работе использовались методы аналитической механики, а именно уравнения Аппеля, а также линеаризация полученных дифференциальных уравнений.

Результаты исследования. Построена математическая модель, которая описывает собственные колебания математического маятника новой конструкции с подвижной (подпружиненной) точкой подвеса с длиной $L$. Модель представляет собой систему диффреренциальных уравнений, полученных с привлечением формализма Аппеля. На их основе после линеаризации нелинейных уравнений установлена формула для частоты малых собственных колебаний маятника с подвижной точкой подвеса.

Выводы. Показано, что частота собственных колебаний нового математического маятника совпадает с частотой собственных колебаний классического математического маятника с эквивалентной длиной подвеса, которая равна $L$ eq $=L+\frac{m g}{k}$. В случае, когда точка подвеса является неподвижной $(k \rightarrow \infty)$, частотная формула превращается в известную фрормулу для частоты малых собственных колебаний классического математического маятника $\omega=\sqrt{\frac{g}{L}}$. Если же величина коэффициента жесткости упругих элементов стремится к нулю $(k \rightarrow 0)$, то частота $\omega$ гасителя также стремится к нулю. Отмечена важная конструктивная особенность предложенного маятника, состоящая в том, что за счет соответствующего выбора трех регулирующих параметров маятника $(k, L, m)$ его частоту по величине при необходимости можно сделать любой в диапазоне от нуля до $\sqrt{\frac{g}{L}}$.

Ключевые слова: математический маятник; подвижная точка подвеса; малые собственные колебания; частота; фрормализм Аппеля; линеаризация.

Рекомендована Радою

факультету прикладної математики

КПІ ім. Ігоря Сікорського
Надійшла до редакції 09 липня 2020 року

Прийнята до публікації 10 грудня 2020 року 